Article

\title{
Assessment of Genetic Diversity of Edible Honeysuckle Monitored through RAPD in Relative to Bioactive Substances
}

\author{
Marcela Cehula ${ }^{1}{ }^{\oplus}$, Jiří Mlček ${ }^{2, *}$, Tünde Juríková ${ }^{3}{ }^{\oplus}$, Jana Žiarovská ${ }^{4}$, Oleg Paulen ${ }^{5}$, \\ Libor Dokoupil $^{6}$, Anna Adámková ${ }^{2}$ (D) and Ramona Babosova ${ }^{7}$ \\ 1 Department of Botany and Genetics, Faculty of Natural Sciences, Constantine the Philosopher University in \\ Nitra, Nábrežie mládeže 91, 94974 Nitra, Slovakia; phd178564@ukf.sk \\ 2 Department of Food Analysis and Chemistry, Faculty of Technology, Tomas Bata University in Zlín, \\ Vavreckova 275, 76001 Zlín, Czech Republic; aadamkova@utb.cz \\ 3 Institute for Teacher Training, Faculty of Central European Studies, Constantine the Philosopher University \\ in Nitra, Dražovská 4, 94974 Nitra, Slovakia; tjurikova@ukf.sk \\ 4 Department of Genetics and Plant Breeding, Faculty of Agrobiology and Food Resources, Slovak University \\ of Agriculture, Trieda A. Hlinku 2, 94976 Nitra, Slovakia; jana.ziarovska@uniag.sk \\ 5 Horticulture and Landscape Engineering Faculty, Slovak University of Agriculture in Nitra, Tr. A. Hlinku 2, \\ 94976 Nitra, Slovakia; oleg.paulen@uniag.sk \\ 6 Department of Breeding and Propagation of Horticultural Plants, Faculty of Horticulture, Mendel University \\ in Brno, Valtická 337, 69144 Lednice, Czech Republic; libor.dokoupil@mendelu.cz \\ 7 Department of Zoology and Anthropology, Faculty of Natural Sciences, Constantine the Philosopher \\ University in Nitra, Nábrežie mládeže 91,949 74 Nitra, Slovakia; rbabosova@ukf.sk \\ * Correspondence: mlcek@utb.cz; Tel.: +420-576-033-030
}

Received: 21 May 2020; Accepted: 16 June 2020; Published: 18 June 2020

\begin{abstract}
This study aimed to analyze the genetic diversity of selected cultivars and clones of Lonicera sp. (edible honeysuckle) from two countries with different climatic and soil conditions. Accordingly, the determination of total polyphenols content (TPC) and total antioxidant activity (TAA) in fruits of Lonicera sp. in 2018-2019 was performed. Applied statistical methods evaluating TPC and TAA were: correlation and regression, ANOVA, and agglomerative hierarchical clustering. The neighbor-joining method and gel images analysis (PyElph software, Pavel and Vasile, Bucharest, Romania) were used for genetic analysis. The average TPC of all cultivars and clones was $5.32 \mathrm{mg} \mathrm{L}^{-1}$ in the year 2018 and $3.78 \mathrm{mg} \mathrm{L}^{-1}$ in 2019. The average TAA values of all samples in 2018 were $8.24 \mathrm{mg} \mathrm{L}^{-1}$, and $9.27 \mathrm{mg} \mathrm{L}^{-1}$ in 2019. Statistically significant correlations between years and cultivars and clones were found. Based on the lengths and number of fragments by random amplified polymorphic DNA (RAPD)-PCR's, it was found that 'clone 5' and 'clone 7' were genetically close to the grown cultivars from the Czech Republic. Therefore, edible honeysuckle fruits are a valuable source of important nutrients for the human body and its health.
\end{abstract}

Keywords: honeysuckle; DNA polymorphism; TAA; TPC

\section{Introduction}

The edible honeysuckle and its fruits, except for their valuable properties, have been underutilized fruit species in Europe. Edible honeysuckle represents shrubs native to the northern hemisphere, especially Russia and Japan. Due to unique antibacterial and anti-inflammatory properties, flowers, buds, leaves, barks, and fruit have been widely utilized for centuries in folk medicine [1]. Edible honeysuckle fruits were found to be rich in phenolic acids, flavonoids (quercetin, rutin, anthocyanins), and ascorbic acid [1,2]. Bioactive compounds' determination has been essential for the inclusion 
of edible honeysuckle in the group of functional food [3]. Blue honeysuckle fruit extract possessed suitable properties for use as a potent hepatoprotective medicinal food [4]. One of the unique traits is high frost resistance, and the others are resistant to plant diseases and pests [2,5]. Furthermore, the growing season's length is significantly reduced due to the early flowering period $[1,3]$.

Analysis of genetic aspects relative to the content of antioxidants in Lonicera kamtschatica (Sevast.) Pojark has been limitedly explored [6,7]. The taxonomic classification of the whole section Caerulea Rehder have not been satisfactorily solved, and it is a matter of the taxonomist's view. The most common concept is to consider only one fruit species L. caerulea L. within the section. The authors decided to accept section subdivision to smaller species and use L. kamtschatica (Sevast.) Pojark., and L. edulis Turcz. ex Freyn. A lot of historical small species are considered synonymous. In terms of taxonomic classification, phylogenetic analyses of breeding plants are necessary [8]. Bioactive substances are produced by plants as secondary metabolites for their defense. In particular, these substances have fungicidal, bactericidal, and biocidal activity, e.g., the protection of plant embryos against harmful UV radiation [9]. These bioactive substances can protect the human body against exogenous and endogenous free radicals [10].

Over the past years, plant breeding has been aimed at the production of large-fruited cultivars with regular fertility, and higher content of polyphenol substances combined with vitamin C. Various breeding programs have been carried out in Europe, USA, and Canada to breed Lonicera kamtschatica plants [11]. Nowadays, scientists have developed several molecular marker methodological procedures for the determination of genetic diversity of genus Lonicera, including random amplified polymorphic DNA (RAPD) [6]; sequence characterized amplified region (SCAR) [8]; inter-simple sequence repeat (ISSR) [9,12]; sequence related amplified polymorphism (SRAP) [13]; etc.

The results of the RAPD analysis revealed significant differences among wild populations and elite bred varieties. Similarly, differences in the DNA of L. caerulea, L. stenantha (Pojark.), and L. kamtschatica (Sevast.) Pojark. were also confirmed [6]. The discovery of the fact that DNA molecule carries genetic information has had an incredible impact on modern breeding methods [14]. The basic chromosome number of the genus Lonicera was described as $(n=x=9)$. However, in the conditions of Russia, there were found edible diploids $(2 n=2 x=18)$ or tetraploids $(2 n=4 x=36)$ [15]. Other strategies that could be used to develop traits in native plants include interspecific hybridization and polyploidization. Genomic mutations are any deviations from the basic diploid $(2 \mathrm{n})$ chromosome number of somatic cell or haploid (n) chromosome number of sex cells, and collectively are called heteroploid or polyploid. In another study, the numbers of chromosomes and karyomorphology of 11 cultivars through four species and the DNA content of 10 cultivars representing six species of Lonicera were analyzed. Between them, the chromosome number of nine cultivars were reported for the first time. Discovered results showed that the basic chromosome number of $x=9$ was constant, and chromosome numbers of $2 \mathrm{n}=2 \mathrm{x}=18,27,36$, or 54 were observed, indicating that polyploids exist in the genus Lonicera. Five cultivars were diploids with $2 \mathrm{n}=2 \mathrm{x}=18$; one cultivar was triploid, four were tetraploids, and one was hexaploid [16]. Similarly, high polymorphism (up to $83.2 \%$ ) of edible honeysuckle-L. caerulea, L. stenantha, and L. kamtschatica — was also pointed out, based on the study of specific RAPD markers [6,17].

Our study aimed to investigate the genetic diversity of selected cultivars and clones of edible honeysuckle plants, according to the predominant group of biologically active ingredients, summarized as the total polyphenols content (TPC) and total antioxidant activity (TAA) of the fruit. The attributes of TPC and TAA were statistically analyzed in the years 2018 and 2019. Finally, this study compared two localities of cultivation in terms of different weather and soil conditions.

\section{Materials and Methods}

The presented research study evaluated the genetic variability of edible honeysuckles in 5 clones, grown in the Slovak Republic, and 5 cultivars, grown in the Czech Republic. Moreover, the content of bioactive substances was determined, relative to genetic variability monitored by RAPD analyses. 


\subsection{Biological Material}

The biological material that was tested for this study included cultivars and clones of species Lonicera kamtschatica (Sevast.) Pojark and Lonicera edulis Turcz. Ex Freyn. Biological material for analysis was collected at the beginning of June 2018 and 2019. To obtain representative samples, it was important to collect berries from different parts of the plants (i.e., top, middle, and bottom) and it was picked about $100 \mathrm{~g}$ of fruits from each bush. The experimental area Žabčice (Czech Republic) is located at an altitude of $177 \mathrm{~m}$ above sea level with a long-term average annual temperature of $9.7^{\circ} \mathrm{C}$ and an average yearly rainfall of $525.0 \mathrm{~mm}$. The second experimental area Nitra (Slovak Republic), is located at an altitude of $167 \mathrm{~m}$ above sea level, with a long-term average annual temperature of $9.4{ }^{\circ} \mathrm{C}$ and an average yearly rainfall of $598.3 \mathrm{~mm}$.

In this research, the following cultivars and clones of edible honeysuckle were chosen: 'Clone 2', 'Clone 3', 'Clone 5', ‘Clone 6', ‘Clone 7' (Slovak republic), 'Pruhonicky 55', 'Gerda', 'Morena', 'Goluboe vreteno', 'Bakcharskaya' (Czech Republic).

Cultivar 'Goluboe vreteno' was cultivated as the first variety of Lonicera kamtschatica (Sevast. Pojark) in Russia. Cultivar 'Bakcharskaya' was cultivated in Russia too, but as a Lonicera turczaninowii. The advantage of Russian cultivars is a relatively uniform term of harvesting, due to the uniform ripening of the berries, high productivity, and early ripening of the berries. However, the fruits are elongated in shape and weight less than $1 \mathrm{~g}$, which is often considered a disadvantage. Cultivars 'Gerda' and 'Morena' were cultivated as varieties of Lonicera caerulea and Lonicera kamtschatica in Sweden. The fruits of the Swedish variety Lonicera kamtschatica are 1.3 to $2.0 \mathrm{~cm}$ long, with a weight of $1.5-2.0 \mathrm{~g}$, and they ripen in mid-May. Fruits contain $6-8 \%$ carbohydrates, $2-3 \%$ organic acids, and $40-70 \mathrm{mg}$ vitamin C/100 g. 'Gerda' was created by crossing cultivar 'Sinnaja ptica', with a mixture of pollen of Lonicera kamtschatica in Research Institute of Fruit "Sady Sibiri". Shrubs form a round and compact dense shape. It is characterized by high frost resistance. The fruits are elongated, smooth with thin skin and sour-sweet taste and matures medium early; the average fertility per bush is $0.56 \mathrm{~kg}$ [18].

Another set of Lonicera sp. clones was obtained from Herbaton s.r.o., Klčov, Slovakia and another one from VUOOD from Bojnice, Slovakia. In 1989 company Herbaton Klčov brought hybrid seed Lonicera kamtschatica from the Research Institute of Genetics in Siberia by M. Lisavenko in Barnaul, Russia. Over the years 1996-2000, a selection base of 2500 mother plants was formed, from which 143 plants were described after achieving fertility. Five of them were chosen for this research.

\subsection{DNA Extraction}

For the RAPD method, the leaves were harvested without visible damage. DNA from $100 \mathrm{mg}$ of fresh young leaves was isolated using the CTAB protocol [19]. The quantity and quality of extracted DNA was measured by Nanophotometer P-Class (Implen, Munich, Germany).

\subsection{RAPD Amplification}

RAPD-PCR's were performed in duplicate volumes of $15 \mu \mathrm{L}$, containing $50 \mathrm{ng}$ of DNA, $7.5 \mu \mathrm{L}$ Combi mastermix (Top-Bio, Vestec, Czech Republic), $1 \mu \mathrm{L}$ primer and $5.5 \mu \mathrm{L}$ water. The thermal cycler (My Cycler, BioRad, Berkeley, California) was programmed for one cycle of $5 \mathrm{~min}$ at $94^{\circ} \mathrm{C}$, followed by 40 cycles of $1 \mathrm{~min}$ at $94{ }^{\circ} \mathrm{C}, 1 \mathrm{~min}$ at $36^{\circ} \mathrm{C}$ and $2 \mathrm{~min}$ at $72{ }^{\circ} \mathrm{C}$, and finally by one cycle of $5 \mathrm{~min}$ at $72{ }^{\circ} \mathrm{C}$.

\subsection{Amplicon Analysis}

Amplification products were separated by electrophoresis (BioRad, Berkeley, California) in $6 \%$ PAGE (30\% acrylamide, 5xTBE, 10\% APS, TEMED). Gels were stained with GelRed (Biotium, San Francisco, USA), visualized by Transilluminator UVP (Fisher Scientific, Leicestershire, England) with documentation system G-Box SynGene and analytic software GeneSnap, (Fisher Scientific, Leicestershire, England) SynGene (Fisher Scientific, Leicestershire, England). Marker GeneRuler ${ }^{\mathrm{TM}}$ DNA Ladder Mix (MBI Fermentas, 100 bp, Vilnius, Lithuania) was used to determine the size of the 
DNA fragments. Ten Lonicera plants were analyzed using two RAPD primers (5'ACCGCGAAGG3' and 5'GGACCCAACC $3^{\prime}$ ), based on the previous results of polymorphic data for tested RAPD primers (data not shown). Only reproducible polymorphic loci of amplified RAPD profiles were scored further to construct dendrograms.

\subsection{Determination of Total Polyphenols Content (TPC) and Total Antioxidant Activity (TAA)}

For both analyses, we used the harvested fruits of honeysuckle. The antioxidant activity was determined by the DPPH method [20], which consists of the sample with DPPH (stable free radical 1,1-diphenyl-2-picrylhydrazyl) by method [5]. We prepared the DPPH stock solution, which contained $0.024 \mathrm{~g}$ DPPH in $100 \mathrm{~mL}$ methanol. After, we prepared DPPH working solution (10 mL DPPH stock solution and $45 \mathrm{~mL}$ methanol). Then, we added $450 \mu \mathrm{L}$ of sample extract and $8.55 \mathrm{~mL}$ working solution to the beaker, well mixed and left in the dark for $60 \mathrm{~min}$. The samples were repeated twice. The measurement took place at $\lambda=515 \mathrm{~nm}$ on spectrometer (Lambda $25 \mathrm{UV} / \mathrm{VIS}$ Spectrometer, PerkinElmer, Cleveland, USA).

The determination of total polyphenols content by the Folin-Ciocalteu method was performed with Folin-Ciocalteu reagent, $1.5 \mathrm{~mL} 20 \% \mathrm{Na}_{2} \mathrm{CO}_{3}$. As first, we made a blanc sample. To a $10 \mathrm{~mL}$ volumetric flask, we added about $5 \mathrm{~mL}$ of distilled water, $0.5 \mathrm{~mL}$ Folin-Ciocalteu reagent, $1.5 \mathrm{~mL}$ of $20 \% \mathrm{Na}_{2} \mathrm{CO}_{3}$, and make up to the mark with distilled water. For our own measurement of samples: to a $10 \mathrm{~mL}$ volumetric flask, we added about $5 \mathrm{~mL}$ of distilled water, $0.1 \mathrm{~mL}(100 \mu \mathrm{L})$ extract sample or standard, $0.5 \mathrm{~mL}$ of Folin-Ciocalteu reagent, $1.5 \mathrm{~mL}$ of $20 \% \mathrm{Na}_{2} \mathrm{CO}_{3}$ with distilled water to mark. After $30 \mathrm{~min}$, the samples were measured. The samples were repeated twice again [21]. The measurement was conducted by $\lambda=765 \mathrm{~nm}$ on spectrometer PerkinElmer (Lambda 25 UV/VIS Spectrometer).

\subsection{Statistical Analysis}

Gel images were analyzed with the use of PyElph software (Project Admins Pavel and Vasile, 2012, version 1.4, Bucharest, Romania) [22]. The homology between the DNA sequences was computed and used to generate phylogenetic trees, that are useful for population genetic studies and taxonomic classification. The values we acquired were recalculated using neighbor-joining [23]. Through the clustering method, we transformed data to create a phylogenetic tree. The distance matrix was used as input. The UPGMA statistical method was used to evaluate this study [22]. PIC (polymorphic information content) marker attributes were scored based on the formula [24]

$$
\text { pic }=1-\sum \text { pij2. }
$$

The values of TAA and TPC were transformed as statistical data for regression and correlation, ANOVA, for the last agglomerative hierarchical clustering method. Data were analyzed by NCSS 2019 software to construct the dendrograms.

\section{Results}

The results showed that the highest total polyphenols content (TPC) in the year 2018 (Figure 1) was measured in the cultivar 'Gerda' $\left(6.27 \mathrm{mg} \mathrm{L}^{-1}\right)$, and the lowest value was determined in the 'clone 3' (4.53 $\left.\mathrm{mg} \mathrm{L}^{-1}\right)$. In the year 2019, there was the highest TPC in the cultivar 'Goluboe vreteno' (5.70 mg L $\left.{ }^{-1}\right)$; on the other hand, 'clone 6' showed the lowest content $\left(2.36 \mathrm{mg} \mathrm{L}^{-1}\right)$. Average total polyphenols content of all cultivars and clones was $5.32 \mathrm{mg} \mathrm{L}^{-1}$ in the year 2018, and there was the average value of TPC $3.78 \mathrm{mg} \mathrm{L}^{-1}$ in 2019. This statistical model was appropriate, which has been demonstrated by regression analysis. There was $31.45 \%$ of explained variability $\mathrm{R}^{2}$, which describe the practical value of the statistical model. The correlation analysis showed the mean rate interdependence between statistical units as a medium. However, there is a positive direct dependence between all pairs. It was found that the level of impact factor of the year is statistically significant $(p \leq 0.05)$ by two-factor ANOVA. 


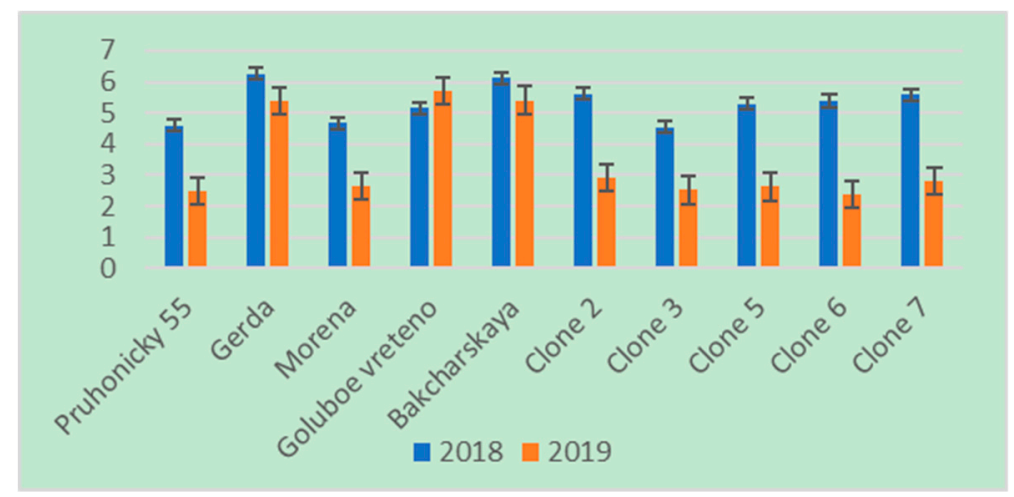

Figure 1. Total polyphenols content (TPC) (polyphenols to gallic acid $\mathrm{mg} \mathrm{L}^{-1}$ ) in fruits of edible honeysuckle cultivars and clones, in the years 2018 and 2019.

Determination of total antioxidant activity (equivalent to TROLOX $\mathrm{mg} \mathrm{L}^{-1}$ ) has shown the following values for the year 2018 (Figure 2): the highest-TAA-'Bakcharskaya' $\left(10.24 \mathrm{mg} \mathrm{L}^{-1}\right)$ and the lowest-TAA-clone $7\left(6.07 \mathrm{mg} \mathrm{L}^{-1}\right)$. In the year 2019, the highest values of TAA were measured at the cultivar 'Gerda' (20.85 $\left.\mathrm{mg} \mathrm{L}^{-1}\right)$, and lowest TAA was determined in the 'clone 3' $\left(5.87 \mathrm{mg} \mathrm{L}^{-1}\right)$. The average TAA value of all samples in 2018 was $8.24 \mathrm{mg} \mathrm{L}^{-1}$, and in 2019, there was $9.27 \mathrm{mg} \mathrm{L}^{-1}$. The model is statistically suitable based on the regression analysis. We also found that there has been $44.55 \%$ of the explained variability $\mathrm{R}^{2}$, thus demonstrating the practical value of the statistical model. The correlation analysis showed the medium degree of interdependence between varieties and years for TAA. Thus, like TPC, TAA between all pairs has a positive direct relationship. It was observed that neither cultivar nor year have a statistically significant effect on antioxidant activity by ANOVA.

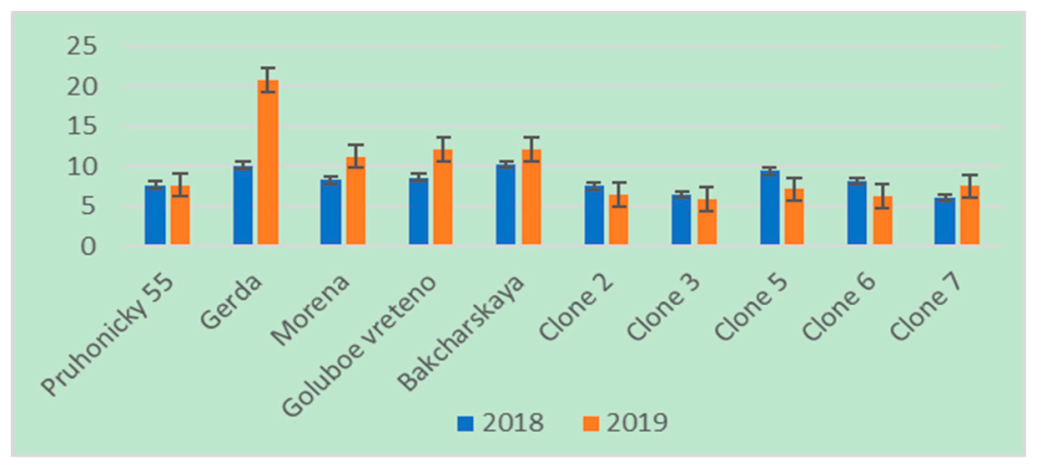

Figure 2. Antioxidant activity (TAA) (equivalent to TROLOX $\mathrm{mg} \mathrm{L}^{-1}$ ) in fruits of edible honeysuckle cultivars and clones in the years 2018-2019.

Cluster analysis based on TPC (2018) distinguished the cultivars into 3 clusters: Cluster 1-'Pruhonicky 55', 'Morena', 'clone 3'; Cluster 2-'Gerda', 'Bakcharskaya' and Cluster 3-'Goluboe vreteno', 'clone 2', 'clone 5', 'clone 6', 'clone 7' (Figure 3a). According to the TPC (2019) cluster analysis three clusters formed, as follows: Cluster 1-'Pruhonicky 55', 'Morena', 'clone 3'; Cluster 2-'Gerda', 'Bakcharskaya' and Cluster 3-'Goluboe vreteno', 'clone 2', 'clone 5', 'clone 6', 'clone 7' (Figure 3b). To sum up, constructed dendrograms were identical in both years, and thus, different soil and climatic conditions did not affect the TPC. Consequently, the plant species can be considered as a factor that influences the TPC in the fruit of the test plants. 


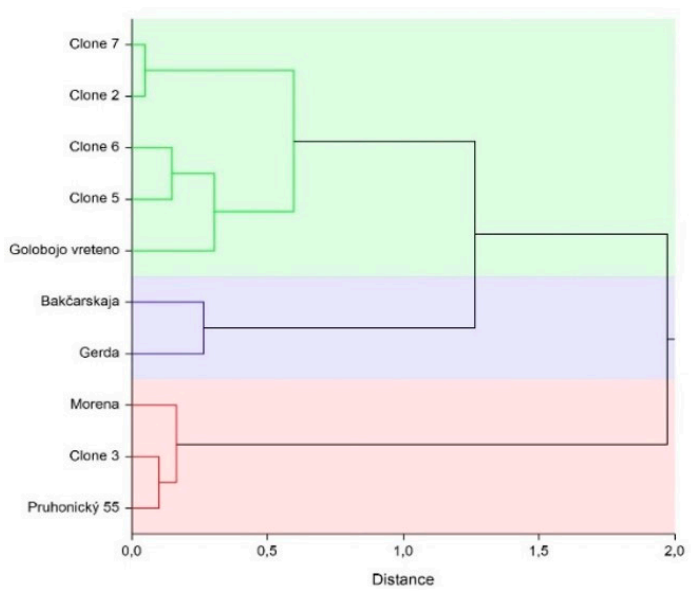

(a)

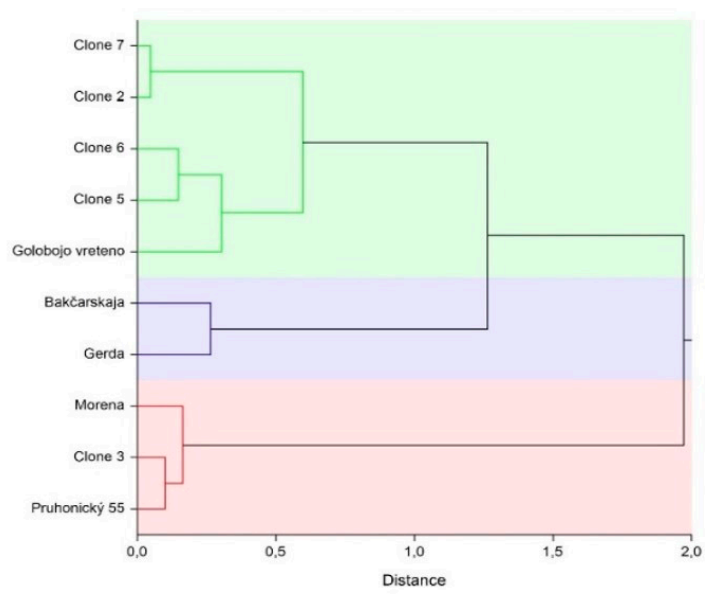

(b)

Figure 3. Cluster analysis based on TPC (polyphenols to gallic acid $\mathrm{mg} \mathrm{L}^{-1}$ ) values, year 2018 (a) and 2019 (b).

Cluster analysis based on TAA (2018) creates 3 clusters: Cluster 1-'clone 3', 'clone 7'; Cluster 2: 'Gerda', 'Bakcharskaya', 'Clone 5' and Cluster 3-'Pruhonicky 55', 'Morena', 'Goluboe vreteno', 'clone 2', 'clone 6' (Figure 4a). According to the variable TAA (2019), three clusters were formed, namely: Cluster 1-'clone 3', 'clone 7'; Cluster 2: 'Gerda', 'Bakcharskaya', 'Clone 5' and Cluster 3-'Pruhonicky 55 ', 'Morena', 'Goluboe vreteno', 'clone 2', 'clone 6' (Figure 4b). It can be deduced that the plant species can be considered as a factor affecting TAA.

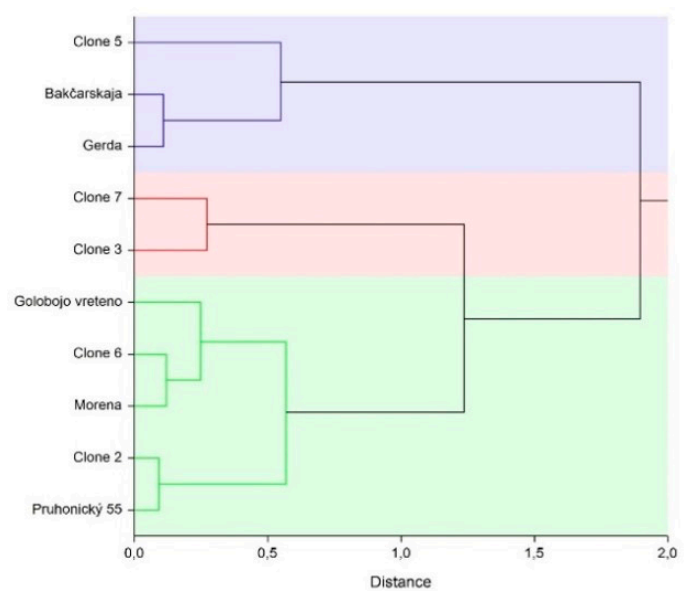

(a)

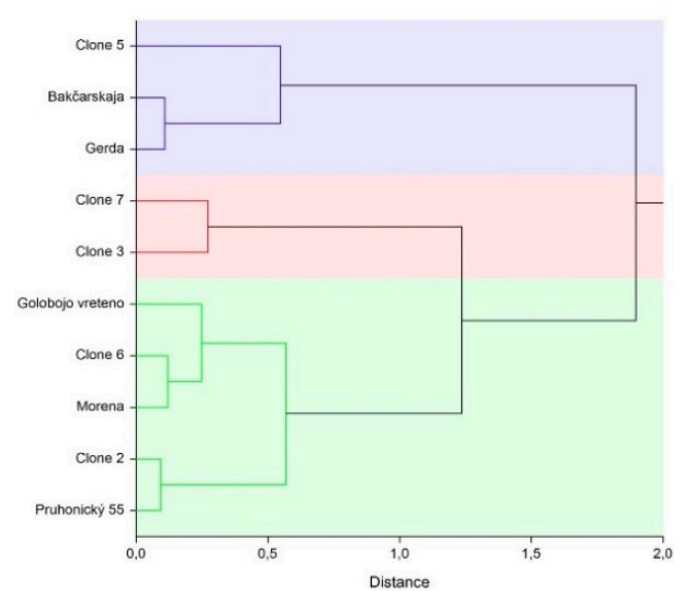

(b)

Figure 4. Cluster analysis based on TAA (equivalent to TROLOX $\mathrm{mg} \mathrm{L}^{-1}$ ) values, year 2018 (a) and 2019 (b).

The genetic diversity of edible honeysuckles was analyzed by the RAPD-PCR's method (Figures 5 and 6). The size of amplicons ranged from 141 to $1187 \mathrm{bp}$. The average number of fragments per sample was 6.3, with polymorphism detecting 98-100\% (5'ACCGCGAAGG3') and 6.3 with the same range of polymorphism percentage ( $5^{\prime}$ GGACCCAACC $\left.3^{\prime}\right)$ (Tables 1 and 2). Polymorphism information content (PIC) value is a reflection of allele diversity and frequency among the varieties. PIC value of both of the RAPD markers were evaluated on the basis of its alleles. In the present study, the level of polymorphism among the analyzed Lonicera genotypes were 0.93 (5'ACCGCGAAGG3') and 0.85 $\left(5^{\prime}\right.$ GGACCCAACC $\left.3^{\prime}\right)$. These values revealed that chosen RAPD markers are effective in the screening of these Lonicera genotypes. The values higher than 0.5 exist for the multiple dominant markers in the case, that equal distribution of amplified alleles was obtained, as the PIC value depends on the distribution frequency of the alleles [25]. The tested cultivars and clones of Lonicera sp. were separated 
into several clusters. A low count of differences between the results gained by two distinct primers was found. Agglomerative hierarchical clustering has shown that, in both cases, 5 clusters were formed. In the first case (used primer 5' ACCGCGAAGG3', Figure 7a), there was separated clusters, namely: Cluster 1-'Pruhonicky 55', 'Morena', 'Gerda'; Cluster 2-'Bakcharskaya', 'Goluboe vreteno'; Cluster 3- 'clone 5', 'clone 7'; Cluster 4-'clone 6', 'clone 3'and Cluster 5-'clone 2'. In the second case (used primer 5'GGACCCAACC 3', Figure 7b), there was formed clusters: Cluster 1-'Pruhonicky 55', 'Morena', 'Gerda'; Cluster 2-'Bakcharskaya', 'Goluboe vreteno', 'clone 5', 'clone 7'; Cluster 3-'clone 6'; Cluster 4-'clone 3'; Cluster 5: 'clone 2'.

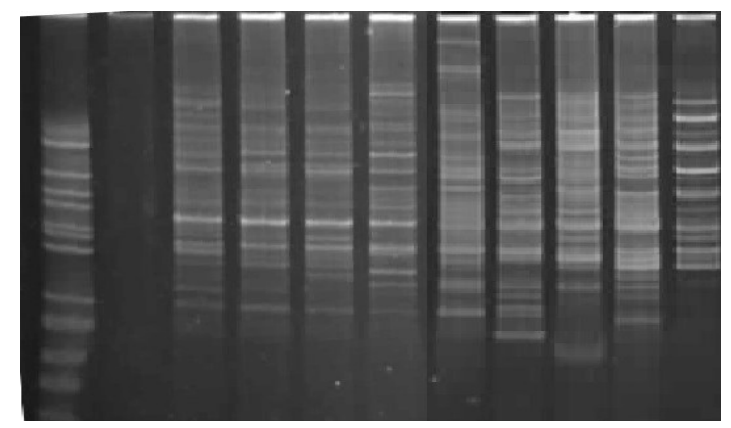

Figure 5. Amplification analysis of the obtained profiles using random amplified polymorphic DNA (RAPD) primer 5'ACCGCGAAGG3' (from left to right-'Clone 2', 'Clone 3', 'Clone 5', ‘Clone 6', 'Clone 7' (Slovak Republic), 'Pruhonicky 55', 'Gerda', 'Morena', 'Goluboe vreteno', 'Bakcharskaya').

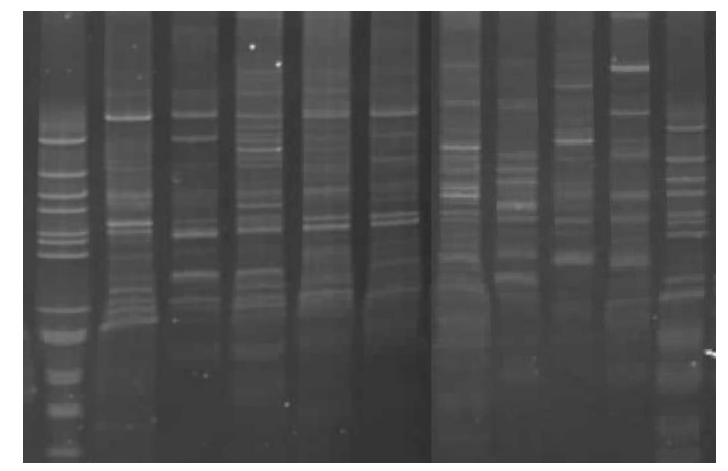

Figure 6. Amplification analysis of the obtained profiles using RAPD primer 5'GGACCCAACC $3^{\prime}$ (from left to right-'Clone 2', 'Clone 3', 'Clone 5', 'Clone 6', 'Clone 7' (Slovak Republic), 'Pruhonicky $55^{\prime}$, 'Gerda', 'Morena', 'Goluboe vreteno', 'Bakcharskaya').

Table 1. Comparison of the lengths of the amplified fragments using the 5'ACCGCGAAGG3' RAPD primer.

\begin{tabular}{ccc}
\hline Sample & No. of Fragments/(\%) Polymorhism & Length of Amplified Fragments (bp) \\
\hline Clone 2 & $6 / 100$ & $344,477,578,648,785,886$ \\
\hline Clone 3 & $4 / 99$ & $141,344,477,656$ \\
\hline Clone 5 & $6 / 100$ & $141,348,473,664,718,910$ \\
\hline Clone 6 & $5 / 100$ & $141,360,461,656,718$ \\
\hline Clone 7 & $5 / 100$ & $133,363,457,664,718$ \\
\hline Pruhonicky 55 & $4 / 100$ & $375,488,715,867$ \\
\hline Gerda & $9 / 98$ & $215,375,488,555,730,824,867,952,999$ \\
\hline Morena & $8 / 100$ & $293,379,477,582,730,867,1101,1183$ \\
\hline Goluboe vreteno & $9 / 100$ & $215,289,375,477,586,629,734,847,1011$ \\
\hline Bakcharskaya & $7 / 100$ & $227,293,500,594,668,757,917$ \\
\hline
\end{tabular}


Table 2. Comparison of the lengths of the amplified fragments using the 5'GGACCCAACC3' RAPD primer.

\begin{tabular}{ccc}
\hline Sample & No. of Fragments/(\%) Polymorhism & Length of Amplified Fragments (bp) \\
\hline Clone 2 & $7 / 99$ & $177,230,313,459,618,755,1156$ \\
\hline Clone 3 & $5 / 98$ & $269,383,564,1046,1174$ \\
\hline Clone 5 & $8 / 100$ & $244,398,586,705,766,986,1040,1168$ \\
\hline Clone 6 & $6 / 98$ & $303,358,602,645,778,1181$ \\
\hline Clone 7 & $6 / 98$ & $313,623,812,939,1070,1187$ \\
\hline Pruhonicky 55 & $10 / 98$ & $82,132,244,287,421,482,551,604,680,806$ \\
\hline Gerda & $7 / 100$ & $302,482,560,701,761,926,1117$ \\
\hline Morena & $3 / 100$ & $368,417,560$ \\
\hline Goluboe vreteno & $5 / 100$ & $438,486,778,926,1035$ \\
\hline Bakcharskaya & $6 / 100$ & $181,280,379,532,869,1401$ \\
\hline
\end{tabular}

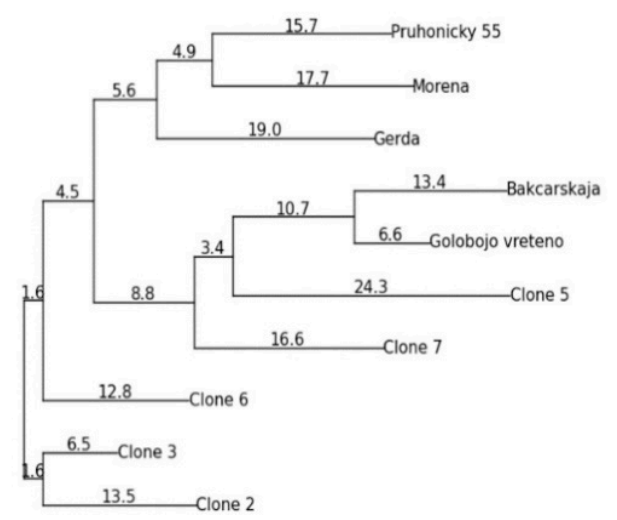

(a)

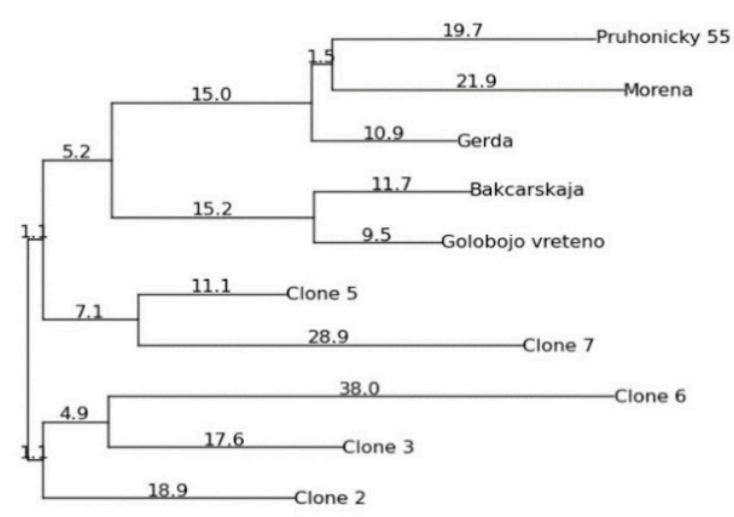

(b)

Figure 7. Phylogenetic tree of 10 Lonicera sp. cultivars and clones created by used RAPD primer 5'ACCGCGAAGG3' (a) and 5'GGACCCAACC3' (b).

\section{Discussion}

In this research, the genetic diversity of plants of the same origin, introduced into two countries with different climatic and soil conditions, was analyzed. It was observed that cultivars from the Czech Republic were separated in one or two clusters, and clones from the Slovak Republic were formed in the other two clusters. This can be caused by different conditions of cultivation (temperature, soil, rainfall) after introduction and by the cross-breeding of different species of Lonicera sp. There are differences in the structure of genotype clusters. Unexpected differences can occur in the case of various polymorphism levels or markers. Therefore, the importance of the number of loci and their coverage of the whole genome is emphasized, in order to obtain reliable genetic information, properties, and relationships between individual cultivars and clones [26]. In our study, we detected small differences between used RAPD markers, which may be caused by levels of polymorphism. RAPD method was recommended by other studies for genetic analysis of Lonicera sp. This method can be easily optimized by increasing the number of RAPD markers (more primers). It involves greater opportunities to detect more reliable genetic relationships between genotypes and taxonomic groups [27,28].

Moreover, primers used in this research revealed a sufficient number of detected bands, and RAPD markers ensured the identification of species. There may be some problems with the methodology used to construct the dendrogram from the calculated distances. One of the limits can be a low level of repeatability of band pattern when the amplification reactions are not optimized [8].

Due to the phenotypic plasticity, the ability to hybridize, and distribution across different ecological areas, it is not straightforward to include honeysuckles in botanical taxonomy [26]. Unfortunately, 
the genetic diversity of the Lonicera genus was explored only in case of decorative species of Lonicera genus-Lonicera japonica and Lonicera confuse. A genetic diversity analysis of L. japonica varieties using RAPD marker was similar to the traditional morphological marker, and both the morphological and RAPD markers were suitable for the genetic diversity evaluation of L. japonica [8]. In another study, specific SCAR markers for the identification of the medicinal plants of L. japonica have been successfully developed. For genetic identification, improved RAPD analysis proved to be a potential suitable molecular technique for profiling the DNA of any species. More specific molecular markers may be RAPD fragments that are cloned and generated into SCAR markers [29]. To evaluate genetic diversity, an experiment was performed between the different germplasm of Lonicera japonica Thunb. materials by using botanical characteristics and RAPD markers. The aim was to elucidate genetic information about the germplasm to breed new varieties. RAPD analysis also clustered these varieties into three distinct groups, of which the first one included 'Xianglei Lonicera' and 'Lonicera confuse'; the second included 'Jufeng 1 ' and 'Jinta 1', while the third one contained 'Jiufeng 1 ', 'Lufengjufeng' and 'Jinhua 3 '. The result of genetic diversity analysis of L. japonica varieties using the RAPD marker was similar to the morphological marker. The morphological and RAPD markers were applied for the genetic diversity analysis of L. japonica germplasm resources [30].

The polyphenol compounds were validated and quantified based on a representative polyphenol standard of the same group. The antioxidant activity of the polyphenol mixtures of the three tissues was determined. The antioxidant activity of the leaves was higher than that of the flowers and stems [31]. In another study, the statistically significant correlation between TPC and TAA assayed 20 cultivars of Lonicera kamtschatica, originating from the area of Žabčice $\left(r^{2}=0.998\right)$, was observed [32]. In the Czech Republic, the TPCs of cultivars which originated from the same area were analyzed. The TPC values ranged from 57.50 to $90.30 \mathrm{mg} / \mathrm{GAE} / \mathrm{L} \mathrm{FW}$ of fruits of different Lonicera kamtschatica [33]. Our research contained a comparison between the years 2018 and 2019, and we demonstrated a statistically significant correlation between two years with various weather. A similar study proved that the content of ascorbic acid and anthocyanins was statistically significant, according to the years 2005-2007 [34]. The effect of the length of sunlight, the amount of total rainfall, and average monthly temperature caused the different content of bioactive compounds in the fruits of edible honeysuckle. Online LC-DPPH and LC Q-TOF MS/MS analysis methods were developed to evaluate the quality of Flos Lonicerae. These methods can provide much more information on chemical properties, as well as information on antioxidant content and antioxidant activity. It is also possible to apply these methods to identify and evaluate plants that are used in medicine.

In comparison with conventional methods, the quantitative method integrated with antioxidant activity may reflect the real quality associated with biological activity. The current opinion can be applied not only to Lonicera plants, but also to other plant species. The online LC-DPPH method would provide a useful and meaningful tool for performing the comprehensive quality control of complex herbal medicines [32].

Here, the traditional approaches were confirmed as still functional ones for the overall diversity characteristics of genomically less known species. Universal markers such as RAPD are still used for different plant species [35] and are chosen not only as a part of different analysis, but as the solo one, too.

\section{Conclusions}

Statistically significant differences and strong correlations between cultivars and clones and the content of TPC and TAA were found. The second statistical factor was the year, thus, we demonstrated statistically significant relations, too. In 2018, higher TPC values than in the year 2019 were determined. Otherwise, in that year 2019, it was observed that TAA values were higher than in 2018. This can be caused by different soil-climatic constraints of the habitat and plant species. Based on phylogenetic trees, we noted that 'clone 5 ' and 'clone 7 ' were separated in close clusters to cultivars from the Czech Republic. 
Author Contributions: Conceptualization, M.C. and T.J.; data curation, M.C. and J.Ž.; formal analysis, M.C.; investigation, M.C.; methodology, M.C., T.J., J.Ž. and J.M.; project administration J.M. and J.Ž.; resources, O.P. and L.D.; software, M.C. and R.B.; supervision, A.A., J.M.; validation, M.C., T.J., J.Ž., J.M. and R.B.; visualization, M.C.; writing—original draft, M.C.; writing—review and editing, T.J., J.Ž., J.M., M.C. and R.B. All authors have read and agreed to the published version of the manuscript.

Funding: This article was supported by the internal grant of TBU in Zlín [No. IGA/FT/2020/010] and by AgroBioTech Research Centre, built in accordance with the project Building "AgroBioTech" Research Centre ITMS 26220220180 and by MZe ČR 206553/2011-17253” Národní program konzervace a využívání genetických zdrojů rostlin a agrobiodiversity".

Conflicts of Interest: The authors declare no conflict of interest.

\section{References}

1. Juríková, T.; Sochor, J.; Mlcek, J.; Balla, S.; Ercisli, S.; Durisova, L.; Kynicky, J. Polyphenolic Compounds and Antioxidant Activity in Berries of Four Russian Cultivars of Lonicera kamtschatica (Sevast.) Pojark. Erwerbs-Obstbau 2014, 56, 117-122.

2. Juríková, T.; Rop, O.; Mlček, J.; Sochor, J.; Balla, S.; Szekeres, L.; Hegedusova, A.; Hubalek, J.; Adam, V.; Kizek, R. Phenolic Profile of Edible Honeysuckle Berries (Genus Lonicera) and Their Biological Effects. Molecules 2012, 17, 61-79. [CrossRef] [PubMed]

3. Li, F.; Zhao, H.; Xu, R.; Zhang, X.; Zhang, W.; Du, M.; Liu, X.; Fan, L. Simultaneous optimization of the acidified water extraction for total anthocyanin content, total phenolic content, and antioxidant activity of blue honeysuckle berries (Lonicera caerulea L.) using response surface methodology. Food Sci. Nutr. 2019, 7, 2968-2976. [CrossRef] [PubMed]

4. Lee, Y.S.; Cho, I.J.; Kim, J.W.; Lee, M.K.; Ku, S.K.; Choi, S.K.; Lee, H.J. Hepatoprotective effects of blue honeysuckle on $\mathrm{CCl}_{4}$-Induced acute liver damaged mice. Food Sci. Nutr. 2018, 7, 322-338. [CrossRef] [PubMed]

5. Quiros, A.R.B.; Frecha-Ferreiro, S.; Vidal-Pérez, A.M.; López-Hernández, J. Antioxidant compounds in edible brown seaweeds. Eur. Food Res. Technol. 2010, 231, 495-498.

6. Naugžemys, D.; Žilinskaite, S.; Kleizaite, V.; Skridaila, A.; Zvingila, D. Assesment of genetic variation among elite and wild germplasm of blue honeysuckle (Lonicera caerulea L.). Balt. For. 2011, 17, 8-16.

7. Cehula, M.; Juríková, T.; Žiarovská, J.; Mlček, J.; Kysel', M. Evaluation of genetic diversity of edible honeysuckle monitored by RAPD in relation to bioactive substances. Potravin. Slovak J. Food Sci. 2019, 13, 490-496. [CrossRef]

8. Cheng, J.L.; Li, J.; Qiu, Y.M.; Wei, C.L.; Yang, L.Q.; Fu, J.J. Development of novel SCAR markers for genetic characterization of Lonicera japonica from high GC-RAMPPCR and DNA cloning. Genet. Mol. Res. 2016, 15. [CrossRef]

9. Kaczmarska, E.; Gawroński, J.; Dyduch-Siemińska, M.; Najda, A.; Marecki, W.; Żebrowska, J. Genetic diversity and chemical characterization of selected Polish and Russian cultivars and clones of blue honeysuckle (Lonicera caerulea). Turk. J. Agric. For. 2015, 39, 394-402. [CrossRef]

10. Sgorbini, B.; Cagliero, C.; Acquadro, S.; Marengo, A.; Cordero, C.; Liberto, E.; Bicchi, C.; Rubiolo, P. Evaluation of volatile bioactive secondary metabolites transfer from medicinal and aromatic plants to herbal teas: Comparison of different methods for the determination of transfer rate and human intake. J. Chromatogr. A 2019, 1594, 173-180. [CrossRef]

11. Singh, P.K.; Singh, R.P.; Singh, P.; Singh, R.L. Chapter 2-Food Hazards: Physical, Chemical, and Biological. In Food Safety and Human Health, 1st ed.; Singh, R.L., Mondal, S., Eds.; Academic Press: London, UK, 2019; pp. 15-65.

12. He, H.Y.; Zhang, D.; Quing, H.; Yang, Y. Analysis of the genetic diversity of Lonicera japonica Thumb. using inter-simple sequence repeat markers. Genet. Mol. Res. 2016, 16, 1-7. [CrossRef] [PubMed]

13. Pan, L.; Zhao, Z.; He, Y.; Li, Y.; Liu, H.; Feng, T.; Zhou, Y. Genetic diversity among five species medicinal plants of Lonicera L. in Guizhou Province by SRAP molecular markers analysis. J. South. Agric. 2018, 49, 2349-2355.

14. Ding, G.; Wang, Y.; Liu, A.; Hou, Y.; Zhang, T.; Bai, G.; Liu, C. From chemical markers to quality markers: An integrated approach of UPLC/Q-TOF, NIRS, and chemometrics for the quality assessment of honeysuckle buds. RSC Adv. 2017, 7, 22034-22044. [CrossRef]

15. Truta, E.; Vochita, G.; Rosu, C.M.; Zamfirache, M.M.; Olteanu, Z.; Oprica, L. Karyotype traits in Romanian selections of edible blue honeysuckle. Turk. J. Biol. 2013, 37, 60-68. 
16. Schierenbeck, K.A.; Hamrick, J.L.; Mack, R.N. Comparison of allozyme variability in a native and an introduced species of Lonicera. Heredity 1995, 75, 1-9. [CrossRef]

17. Alberts, B.; Johnson, A.; Lewis, J.; Morgan, D.; Raff, M.; Roberts, K.; Walter, P. Cells and genomes. In Molecular Biology of the Cell, 6th ed.; Lewis, S.G., Zayatz, E., Eds.; Garland Science: New York, NY, USA, 2014; pp. 1-42.

18. Li, Y.-J.; Chen, J.; Li, Y.; Li, P. Identification and quantification of free radical scavengers in the flower buds of Lonicera species by online HPLC-DPPH assay coupled with electrospray ionization quadrupole time-of-Flight tandem mass spectrometry. Biomed. Chrom. 2011, 26, 449-457. [CrossRef]

19. Rogers, S.O.; Bendich, A.J. Extraction of total cellular DNA from plants, algae and fungi. In Plant Mol. Biol. Manual, 1st ed.; Gelvin, S.B., Schilperoort, R.A., Eds.; Springer: Dordrecht, Germany, 1994; pp. 183-190.

20. Paulová, H.; Bochořáková, H.; Táborská, E. Metody stanovení antioxidační aktivity př́rodních látek in vitro (Methods of determination of antioxidant activity of natural substances in vitro). Chem. Listy 2004, 98, 174-179. (In Czech language)

21. Seo, O.N.; Kim, G.S.; Park, S.; Lee, J.H.; Kim, Y.H.; Lee, W.S.; Lee, S.J.; Kim, Y.; Jin, J.S.; Choi, S.K.; et al. Determination of polyphenol components of Lonicera japonica Thunb. using liquid chromatography-tandem mass spectrometry: Contribution to the overall antioxidant activity. Food Chem. 2012, 134, 572-577. [CrossRef]

22. Pavel, A.B.; Vasile, C.I. PyElph-A software tool for gel images analysis and phylogenetics. BMC Bioinform. 2012, 13, 9. [CrossRef]

23. Nei, M.; Li, W.H. Mathematical model for studying genetic variation in terms of restriction endonucleases. Proc. Natl. Acad. Sci. USA 1979, 76, 5269-5273. [CrossRef]

24. Botstein, D.; White, R.L.; Skalnick, M.H.; Davies, R.W. Construction of a genetic linkage map in man using restriction fragment length polymorphism. Am. J. Hum. Genet. 1980, 32, 314-331. [PubMed]

25. Chesnokov, Y.V.; Artemeyeva, A.M. Evaluation of the measure of polymorphism information of genetic diversity. Agric. Biol. 2015, 50, 571-578.

26. Holubec, V.; Smekalova, T.; Leisova-Svobodova, L. Morphological and molecular evaluation of the Far East fruit genetic resources of Lonicera caerulea L.-vegetation, ethnobotany, use and conservation. Genet. Resour. Crop Evol. 2019, 66, 121-141. [CrossRef]

27. Naugžemys, D.; Žilinskaitè, S.; Denkovskij, J.; Patamsytė, J.; Literskis, J.; Žvingila, D. RAPD based study of genetic variation and relationships among Lonicera germplasm accessions. Biologija 2007, 53, 34-39.

28. Fu, J.; Yang, L.; Khan, A.; Mei, Z. Genetic characterization and authentication of Lonicera japonica Thunb. by using improved RAPD analysis. Mol. Biol. Rep. 2013, 40, 5993-5999. [CrossRef]

29. Hui, J.X.; Wen, S.C. Genetic diversity analysis of seven varieties of Lonicera japonica Thunb. J. South. Agric. 2011, 42, 831-834.

30. Yang, L.; Khan, A.; Mei, Z.; Yang, M.; Zhang, T.; Wei, C.; Yang, W.; Zhu, L.; Long, Y.; Fu, J. Development of RAPD-SCAR markers for Lonicera japonica (Caprifolicaceae) variety authentication by improved RAPD and DNA cloning. Rev. Biol. Trop. 2014, 62, 1649-1657. [CrossRef]

31. Becker, R.; Dashbaldan, S.; Pączkowski, C.; Golis, T.; Szakiel, A. Comparison of steroids and triterpenoids in leaf cuticular waxes of selected Polish and Russian cultivars and genotypes of edible honeysuckle. Phytochem. Lett. 2019, 30, 238-244. [CrossRef]

32. Matuškovič, J.; Juríková, T.; Jurík, I.; Šimko, J.; Gazdík, Z. The content of anthocyanins and ascorbic acid in the genofond of 22 clones of Lonicera kamtschatica (Sevast.) Pojark. GERDA/25. Agriculture 2009, 55, 88-94.

33. Sochor, J.; Jurikova, T.; Pohanka, M.; Skutkova, H.; Baron, M.; Tomaskova, L.; Balla, S.; Klejdus, B.; Pokluda, R.; Mlcek, J.; et al. Evaluation of Antioxidant Activity, Polyphenolic Compounds, Amino Acids and Mineral Elements of Representative Genotypes of Lonicera edulis. Molecules 2014, 19, 6504-6523. [CrossRef]

34. Rop, O.; Řezníček, V.; Mlcek, J.; Juríková, T.; Balík, J.; Sochor, J.; Kramarová, D. Antioxidant and radical oxygen species scavenging activities of 12 cultivars of blue honeysuckle fruit. Hort. Sci. 2011, 38, 63-70. [CrossRef]

35. Vivodík, M.; Saadaoui, E.; Balážová, Ž.; Gálová, Z.; Petrovičová, L. Genetic diversity in Tunisian castor genotypes (Ricinus communis L.) detected using RAPD markers. Potravin. Slovak J. Food Sci. 2019, 13, $294-300$. [CrossRef]

(C) 2020 by the authors. Licensee MDPI, Basel, Switzerland. This article is an open access article distributed under the terms and conditions of the Creative Commons Attribution (CC BY) license (http://creativecommons.org/licenses/by/4.0/). 